\title{
Justyna Bucknall-Hołyńska
}

Justyna Bucknall-Hołyńska - adiunkt w Zakładzie Wiedzy o Sztuce Instytutu Polonistyki i Kulturoznawstwa Uniwersytetu Szczecińskiego. W latach 2003-2008 była prezeską Niezależnego Kina w Miejskim Ośrodku Sztuki w Gorzowie Wielkopolskim, następnie założyła Szkołę Języka Polskiego dla obcokrajowców. Naukowo zajmuje się filmem, kulturą audiowizualną i nowymi mediami, a prywatnie pozostaje miłośniczką podróży, fotografii i jogi. Współredaktor tomu Władcy torrentów. Wokół angażującego modelu telewizji. 


\section{Japońskie reality show z perspektywy zachodniego widza}

DOI: http://dx.doi.org/10.12775/LC.2014.041

$\mathbf{N}$

a tle wszystkich światowych produkcji japońskie programy typu reality show wydają się wyjątkowe i unikalne, a tym samym trudne do zrozumienia dla widza spoza Kraju Kwitnącej Wyspy. Mimo to z roku na rok zainteresowanie nimi rośnie. Wynika ono z wyjątkowej pomysłowości Japończyków i ich kultury, tak odmiennej od reszty świata, oraz specyficznego charakteru samych audycji telewizyjnych wyróżniających się: jaskrawą estetyką, nadmierną ruchliwością, częstotliwością zmian, dojmującym hałasem, oraz stopniem pomysłowości i okrucieństwa. Wszystko to nie przestaje zadziwiać i gorszyć. Warto przyjrzeć się najpopularniejszym produkcjom, by lepiej zrozumieć ich charakter i dostrzec różnicę między japońskimi a zachodnimi wytworami, a także zastanowić się nad istotą ich fenomenu.

1.

Wśród japońskich programów typu reality dominuje typ modern game show. To nowoczesny teleturniej, w którym w każdym epizodzie inni bohaterowie rywalizują między sobą o wygraną, biorąc udział w różnego typu konkurencjach (fizycznych bądź umysłowych). Dzięki swej unikalnej formule, spotykają się z różnymi anglojęzycznymi nazwami: japanese quircky game shows, japanese style variety game shows, a także japanese-style extreme shows ${ }^{1}$, co świadczy o ich wpływie na inne produkcje $\mathrm{e}^{2}$. Zyskały one światową popularność w ostatnich latach dzięki emisji poza granicami kraju, sprzedaży wybranych formatów ${ }^{3}$, a także ze względu na ich niespotykany charakter, który zaciekawia tysiące internautów próbujących dowiedzieć się czegoś więcej na ten temat. Trzeba zaznaczyć, że w każdym państwie zda-

\footnotetext{
1 A. Hill, Reality Tv: Audiences and Popular Factual Television, London-New York, 2005, s. 35.

2 Zob. http://www.today.com/id/25338239/site/todayshow/ns/today-entertainment/t/turning-japanese-game-show -style/\#.UQuX-WYx-3U (stan na dzień: 22.11.2012).

${ }^{3}$ K. Abuchi, Contra-Flows or the Uneven Globalization? Japanese media in the Global Agora, [w:] Cultural Logic Media on the Move: Global Flow and Contra-Flow, red. D. K. Thussu, New York 2007, s. 64.
} 
Tokio, Shibuya, luty 2011

(fot. S. Kołos)

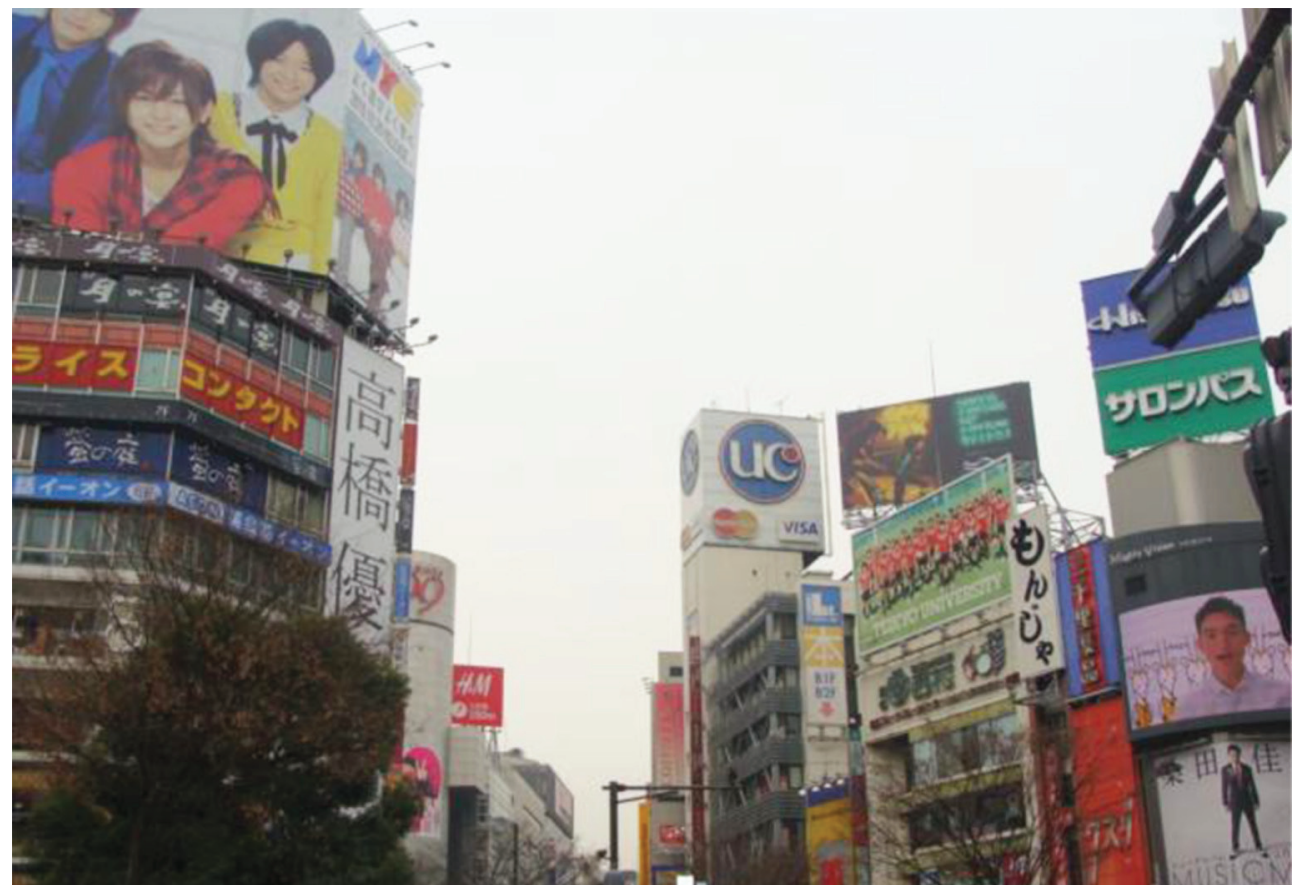

rzają się programy, które zaskakują pomysłowością, osobliwością, szaleństwem, stopniem niebezpieczeństwa czy bezmyślności (np. w Wielkiej Brytanii Distraction, Don't Scare The Hare; w Hiszpanii The Great Game Of The Goose, we Włoszech The Beauty And The Geek, w Indiach Dadagiri, w Danii i Norwegii Total Blackout), jednak w Japonii częstotliwość ich występowania świadczy o pewnej normie. Dowodem niech będzie fakt, że Japończycy nie kupują formatów z innych krajów, uważają je za zbyt nudne czy nieprzystające do ich kultury ${ }^{4}$; poza tym japońskie reality game shows zaczęły być produkowane na szerszą skalę już w latach 80., a więc wcześniej niż w Europie i Ameryce, i od razu przybrały obecny charakter ${ }^{5}$, o czym w dalszej części artykułu.

W wielu krajach reality game show dzielą się na różne podtypy, np. quiz shows (teleturnieje, w tym word games czy puzzle - zabawy słowne), musical game shows (konkursy muzyczne), stunt shows (wyczynowe), card/board games (gry karciane, planszowe) ${ }^{6}$. Jak można zauważyć, przyglądając się przykładom poniżej, japońskie produkcje nie mieszczą się w tych kategoriach. Najpopularniejsze i wzbudzające najwięcej emocji u zachodniego odbiorcy $^{7}$ programy ostatnich lat to ${ }^{8}$ :

\footnotetext{
${ }^{4}$ K. Abuchi, op. cit., s. 64

${ }^{5}$ U. Rohn, Cultural Barriers to the Success of Foreign Media Content: Western Media in China, Indie, and Japan, Frankfurt am Main 2010, s. 303.

${ }_{6}$ Zob. http://gameshows.about.com/od/gameshowsaz/tp/Game-Show-Genres.htm [stan na dzień: 23.11.2012].

7 D. Murphy, The Five Most Insane Japanese Game Shows, [w:] http://www.esquire.com/the-side/video/ insane-japanese-game-shows [stan na dzień: 25.11.2012].

${ }^{8}$ Niektóre z nich składają się na komediowy program z rodzaju variety show zatytułowany Downtown no Gaki no Tsukai ya Arahende!! czy krócej Gaki no Tsukai emitowany nieprzerwanie w Nippon TV od 1989 r. Zob. http://en.wikipedia.org/wiki/Downtown_no_Gaki_no_Tsukai_ya_Arahende!! [stan na dzień: 25.11.2012].
} 
Marshmallow Eating Contest (in. Marshmallow Rubber Band). Drużyna składająca się z pięciu mężczyzn ma za zadanie zjeść bez pomocy rąk wiszące na sznurkach cukierki piankowe (marchmallows), w czym przeszkadza im przeciągnięty przez twarz sznur, który przy każdej próbie uchwycenia obiektu deformuje twarz, co rejestrują kamery w zbliżeniu i co wywołuje u widzów, szczególnie przed telewizorami, śmiech.

Komodo Dragon. Głowy kilku kobiet oplecione surowym mięsem zostają umieszczone w szklanych skrzyniach z największą współcześnie żyjącą jaszczurką (jej długość to $3,5 \mathrm{~m}$, waga $150 \mathrm{~kg}$, szczęka uzbrojona w 60 zębów, a siła uderzenia ogonem sięga 2 ton) ${ }^{9}$. Ta z uczestniczek, która wytrzyma najdłużej tę groźną sytuację, wygrywa.

Ball Buster. Sześciu mężczyzn ustawionych wprost do kamery na specjalnych maszynach przypominających katapulty (zwanych Chinko Machine; to też inna nazwa programu) ma kolejno do wypowiedzenia zdania złożone z trudnych słów, tzw. łamańców językowych. Ten, któremu uda się wyartykułować całość poprawnie, zostaje nagrodzony brawami, ten, który się pomyli, karą - uderzeniem w krocze, co wywołuje spowodowane bólem krzyki, skurcze ciała oraz wrzaski pozostałych uczestników i publiczności przeplatane salwami śmiechu. Trzeba dodać, że przez całą emisję programu tylko jednemu uczestnikowi udało się uniknąć konfrontacji z penis machine.

Silent (Quiet) Library. Przypomina rosyjską ruletkę. Każdy z sześciu grających siedzących przy jednym stole w publicznej bibliotece wyciąga za każdym razem od nowa rozdawane karty. Ten, który trafi na kartę $\mathrm{z}$ literą $\mathrm{X}$, musi podjąć wyzwanie polegające na zachowaniu ciszy podczas wykonywanej na nim kary cielesnej (np. kilkukrotne ciosy kijem bejsbolowym, uderzenie w krocze wspomnianą wyżej maszyną, bolesny „masaż stopą” przyrodzenia, położenie gorącego kożucha mleka na czoło, wykrzywienie twarzy pończochą etc.). Kary wykonywane są przez przebranych w różne kostiumy mężczyzn z zewnątrz. Towarzyszy im bezskutecznie tłumiony chichot uczestników oraz krzyk i płacz przegranych. Program wywołuje tak duże kontrowersje, a jednocześnie fascynuje, że znajduje wielu naśladowców, szczególnie wśród amerykańskich studentów. Ich zabawy można oglądać w serwisie internetowym YouTube.

Bug Game. Podzieleni na dwie dziesięcioosobowe drużyny zawodnicy przebrani za robaki mają za zadanie przeskoczyć ustawioną dość wysoko tyczkę. Ten, któremu się to nie uda (a nie udaje się raczej nikomu, gdyż poprzeczka zawieszona jest zbyt wysoko), zostaje unieruchomiony (siłą, często brutalnie) przez chmarę człekokształtnych robaków (kobiety w przebraniach), a w jego twarz zostaje „wdmuchany” cuchnący zapach wywołujący odruch wstrętu i obrzydzenia.

Programy te, zwane gambaru, czyli rodzaj show pod hasłem: „Dalej, do dzieła! Uda ci się!”10, nie są najbardziej ekstremalnymi w japońskiej telewizji. Do tych należy choćby Susunu! Denpa Shonen z 1998 roku, w którym japoński komik Tomoaki Hamatsu został zamknięty w ciasnym mieszkaniu bez ubrania i żywności w zupełnym odcięciu od świata, na czas wygrania miliona jenów w postaci jedzenia i towarów wygranych w prasowych konkursach, co zajęło mu rok ${ }^{11}$ czy tamtejsza Candid Camera ${ }^{12}$. Natomiast wyżej omówione reality game show są bardzo powszechne, a tym samym reprezentatywne. Ich wyjątko-

\footnotetext{
9 http://en.wikipedia.org/wiki/Komodo_dragon [stan na dzień: 26.11.2012].

10 Ibidem, s. 193.

11 Zob. S. Brenton, R. Cohen, Polowanie na ludzi, tłum. L. Stawowy, Warszawa 2004, s. 108-109.

12 M. Walker, Get Real! The Untold Story: Sexy, Scary, Scandalous World of Reality TV!, Phoenix 2008, s. 13.
} 
wość polega na postawieniu uczestników przed niezwykle trudnymi zadaniami, najczęściej sprawnościowymi, co jest bardzo ciekawe ze względu na fakt, że Japończycy nie są narodem zbyt wysportowanym. Lubią sport, ale tak naprawdę wolą go oglądać w telewizji czy na stadionie niż uprawiać samemu ${ }^{13}$. Pokazywane w czasie prime-time nowoczesne teleturnieje dostarczają Japończykom podobnych wrażeń (najlepiej to widać na przykładzie bardzo popularnego stunt show - Ninja Warrior) ${ }^{14}$. W programach tych zmagający się z zadaniami uczestnicy nie tyle są nagradzani za ich poprawne i szybkie wykonanie, ile karani za błędy $\mathrm{w}$ realizacji, dlatego nazywa się je batsu games (ang. penalty games), czyli teleturniejami, w których nie chodzi o nagrodę, ale o karę. Ten, kto przegrywa, a przegrywa niemal każdy, doświadcza czegoś nieprzyjemnego bądź bolesnego. Stosowane kary mają charakter fizyczny. To każdorazowo wywołanie cierpienia, sprawienie dyskomfortu lub w najlepszym razie wstydu lub upokorzenia. Wydawać by się mogło, że przyświecającym im celem jest pokazywanie ludzkiego cierpienia i możliwych do zniesienia granic, bowiem ich bezwzględność zawiera się także w rodzaju zadań nie do wykonania (ekstremalne wyczyny sportowe, konkurencje obdzierające z godności, jedzenie odpychających rzeczy etc.), tak jednak nie jest, o czym za chwilę. Zwycięzca zadowala się samym faktem wykonania go, aplauzem i uznaniem publiczności zgromadzonej w studiu, a tym samym uniknięcia kary, a nie nagrodą. Nie o wygraną jednak w tych programach chodzi, ale o to, by być zabawnym i się pośmiać. Efekt komiczny wynika tu nie tyle z patrzenia na wykonywanie kary, ile z reakcji prowadzącego, innych uczestników na to, co się dzieje z przegranym oraz samego „krzywdzonego”, jego odruchami i odgłosami.

Warto też wspomnieć o randze i roli prowadzącego. Są to japońscy celebryci wchodzący w rolę boke - głupka, klauna, będącego całkowitym przeciwieństwem politycznej poprawności, który bez mrugnięcia okiem wystawia swych gości na pośmiewisko, serwuje zadania graniczące ze średniowiecznymi torturami i śmieje się do rozpuku z niemożliwości ich realizacji, a następnie wymierzanej kary ${ }^{15}$. Najpopularniejsi z nich, jak Hitoshi Matsumoto czy Masatoshi Hanada, charakteryzują się: umiejętnością zachowania pełnej powagi, stosowanym na szeroką skalę sarkazmem, dużym temperamentem przejawiającym się w nadmiernej ruchliwości i krzykliwości, przesadną, niemal teatralną reakcją na niespodziewane sytuacje oraz, co niespotykane w innych kulturach, sadystycznymi upodobaniami.

Uczestnikami batsu games są zazwyczaj mężczyźni w młodym lub średnim wieku, rzadziej kobiety, niezwykle poważnie podchodzący do najbardziej niedorzecznego zadania, wszak powszechnie wiadomo, że Japonia to kraj samurajów, gdzie dyscyplina, honor i poświęcenie są nadal najważniejszymi wartościami. Przebierani są w wymyślne kostiumy (co świetnie obrazuje upodobanie Japończyków do zabawy wizerunkiem i wcielania się w różne role) lub tradycyjne, aczkolwiek jaskrawe kimona. Publiczność to z reguły młodzi ludzie bardzo żywo i głośno reagujący na to, co się dzieje na scenie. Wydaje się, że czas spędzony w studiu jest dla nich okazją do chwilowej identyfikacji, najczęściej z boke - kreacją prowadzącego, jak również ekspresji skrywanych na co dzień emocji.

$\mathrm{Z}$ jakich jeszcze powodów Japończycy oglądają batsu games z niesłabnącym zaintere-

13 R. Tomański, Tatami kontra krzesła. O Japończykach i Japonii, Warszawa 2011, s. 176.

14 Największe i nieco inne od pozostałych show, bo obejmujące setkę uczestników - japońskich sportowców mających do pokonania w ograniczonym czasie niemal niemożliwy do przejścia tor przeszkód równający się często z olimpijskimi bądź ekstremalnymi zadaniami. To rodzaj survival game - gry, w której nie chodzi o sport, lecz o przetrwanie.

15 R. Tomański, op. cit., s. 190. 
sowaniem? Jaką przyjemność z ich oglądania czerpią? Jak wyjaśnić ich pasję wymierzania wszelkiego typu kar i obserwowania wywołanych bólem reakcji? Dlaczego wymyślają audycje telewizyjne, które z perspektywy cywilizacji okcydentalnej uderzają w godność uczestników? I dlaczego naród znany ze swej powagi, powściągania uczuć i spokoju ogląda tak prymitywny humor, śmiejąc się przy tym histerycznie? Na te i inne pytania warto odpowiedzieć, przyglądając się wybranemu programowi. By przedstawić go z perspektywy zachodniego widza, do analizy została wybrana jedyna w swoim rodzaju japońsko-amerykańska produkcja ${ }^{16}$.

\section{2.}

I Survived a Japanese Game Show (Przeżyłem japoński game show) znany pod wcześniejszym tytułem Big in Japan czy japońskim Majide, co po angielsku wyraża się w słowach: You have to be crazy! Is it true? Seriously? czy No kidding!, to amerykański reality show, ukazujący się jednocześnie w japońskiej oraz amerykańskiej telewizji w czasie prime-time. Logo programu przedstawia wizerunek węża z napisem HONKI de (本気で), co oznacza 'na poważnie', 'na gorąco'. Powstały dwie jego serie, pierwsza w 2008 roku, a druga, zdjęta z ekranów na skutek słabej oglądalności, w roku 2009.

Pomysł programu opierał się na pobycie w Japonii dwunastu Amerykanów podzielonych na dwie grupy rywalizujące ze sobą o zwycięstwo w poszczególnych zmaganiach, typowych japanese style game show. Zwycięska grupa po każdej konkurencji zostaje nagrodzona, przegrana natomiast ukarana. Dodatkowo za każdym razem z pokonanych wybierane są dwie osoby do dodatkowej, eliminacyjnej konkurencji, która ma zdecydować o tym, kto następny opuści studio i kraj. Zwycięzca serii wygrywa 250 tysięcy dolarów. Program zdobył dwukrotnie nagrodę na najlepsze reality show w 2009 roku.

I Survived a Japanese Game Show to oryginalny, bo międzykulturowy (i to obejmujący dwie skrajnie różne kultury i dwa języki), non-scripted entertainment ${ }^{17}$ wyprodukowany przez amerykańskich producentów, ale wpisujący się w zakorzenione w japońskiej kulturze i omówione wyżej teleturnieje telewizyjne. To też ciekawy przykład połączenia kilku podgatunków reality, inaczej mash-up reality, program-hybryda łączący najpopularniejsze w Japonii i omówione wyżej modern game show oraz niepopularne w tym kraju, a najpopularniejsze w Europie i Ameryce: reality game show, inaczej - playoff reality (zadania, prowadzący, sędzia, uczestnicy przebywający w odosobnieniu, eliminacje, nagrody i kary); scientific reality show (wyprawy w nieznane, poznawanie obcego miejsca, kultury) oraz adventure game show (widowiska przygodowe z ekstremalnymi zadaniami, systemem nagród i kar). Zatem, poza rywalizacją, uczestnictwem w modern game show, ta audycja telewizyjna przedstawia podpatrywany przez wiele kamer pobyt Amerykanów w Tokyo, ich wspólne egzystowanie na ograniczonej przestrzeni jednego domu w oderwaniu od innych osób oraz mediów, czyli

${ }^{16}$ Właściwie I survived a Japanese Game Show został wyprodukowany przez Amerykanów, głównie A. Smith \& Co. Productions (producentów m.in. Hell's Kitchen Gordona Ramsaya), emitowany przez Disney/ABC's Greengrass Productions, a twórcami formatu są duńscy producenci Karsten Bartholin i David Sidebotham z Babyfoot ApS, jednak jego realizacja leżała po stronie japońskiej. Zob. http://en.wikipedia.org/wiki/ I_Survived_a_Japanese_Game_Show [stan na dzień: 26.11.2012].

${ }_{17}$ W tym przypadku inne określenie na program typu reality show. 
playoff reality. Tę dwudzielność programu podkreślają dwie zamknięte przestrzenie - studia i domu (oraz sporadycznie jedynie, jako kara lub nagroda, otwarta przestrzeń miasta czy obszarów turystycznych) oraz dwaj gospodarze prowadzący poszczególne części.

I survived a Japanese Game Show jako współczesny teleturniej łączy w sobie konkurencje charakteryzujące konkretne, i po części omówione wyżej, japońskie game shows, dlatego nie ma tu tych samych zadań do wykonania, pomysłowość japońskich producentów bije na głowę zachodnie produkcje. To m.in. próba zrzucenia przebranych za króliki zawodników, których celem jest przeniesienie japońskiego jedzenia przez wzniesiony nad basenem śliski pomost; rozbicie głową plastikowych puszek przez uczestników wyrzucanych w powietrze jak z torpedy; trafienie $\mathrm{w}$ wiszącą na linach osobę kubłami z farbą. To tylko niektóre przykłady możliwe do wymienienia ${ }^{18}$. Zadania wymagają niespotykanej sprawności fizycznej, dlatego niektórzy zawodnicy rozgrzewają się przed nimi. Każdorazowo jedna z drużyn zostaje nagrodzona i ukarana. Przykładowe nagrody to: kolacja i gorąca kąpiel przy zachodzie słońca $\mathrm{z}$ widokiem na Fiji, przelot helikopterem nad Tokyo czy pobyt w japońskich gorących źrodłach. Kary to przede wszystkim praca: czyszczenie tokijskiego metra, wożenie rikszą, zajęcia w kasynie czy na farmie ryżu. Teleturniej przebiega niezwykle żywiołowo. Wszyscy, nie tylko zawodnicy, energicznie się poruszają. Szybko zmieniana jest sceneria. Ujęcia w studiu i poza nim są bardzo dynamiczne, to: podzielony ekran, liczne zoomy, szybkie zmiany punktów widzenia i ruchów kamery, montaż synchroniczny. Wzbogacają je zdjęcia spowolnione szczególnie w ujęciach grymasów twarzy (funkcja komiczna) oraz przyspieszone (czas zagęszczony, utrzymanie przyjętego tempa narracji) głównie podczas trwania dłuższych czynności.

Program od strony wizualnej przesycony jest jaskrawymi kolorami. Zawodnicy występują w kostiumach o intensywnych kolorach podkreślających ich często odbiegającą od perfekcji figurę, co wywołuje dodatkowo śmiech (królik, pająk, robak, statuetka Nobla). W prezentujących na ekranie kadrach występuje chaos i przesyt wynikający głównie z nałożenia na siebie dwóch obrazów - tła, czyli publiczności, zawodników, prowadzącego i jego pomocników oraz plansz z animacjami wyjaśniającymi widzom poszczególne zadania, przerywnikami informującymi o przebiegu show, zabawnymi „wstawkami” urozmaicającymi prezentowany obraz. Oprócz tego pojawiają się ujęcia zza kulis obnażające proces realizacji programu, w których możemy poznać nawet opinie członków ekipy realizatorskiej na temat prezentowanych treści. Warstwa wizualna wydaje się najważniejsza dla Japończyków, stąd też tak powszechne upodobanie do kostiumów, stylizacje.

Przesyt cechuje również warstwę wokalną show, wyraża się ona przede wszystkim w nieustającym krzyku prowadzącego, publiczności i zawodników. Ten program, jak i inne japońskie reality game show, jest bardzo głośny (nie ma w nim ani minuty ciszy), cały czas coś się dzieje i to w zawrotnym tempie. Słyszymy i oglądamy na ekranie rozgrywające się zawody, na co nałożony jest jeszcze głos z offu narratora wprowadzającego do każdego odcinka krótkim wstępem o Japonii i jej kulturze oraz zawodników wypowiadających się wprost do kamery po odbytych konkurencjach (rodzaj futuro- bądź introspekcji); zwierzają się oni widzowi z tego, jak się czuli, co myśleni w trakcie wykonywania poleceń. Po każdym zadaniu wszyscy krzyczą Hai majide!, wykonując przy tym specyficzny ruch dłonią (wyciągnięta

${ }^{18}$ Ich szczegółowe opisy znajdują się na stronach internetowych: http://en.wikipedia.org/wiki/ I_Survived_a_Japanese_Game_Show_(season_1) oraz http://en.wikipedia.org/wiki/l_Survived_a_Japanese_Game_ Show_(season_2) [stan na dzień: 26.11.2012]. 
przed siebie ręka z trzema - pierwszymi od kciuka - palcami wyprostowanymi) oznaczająca gest: Let's go!. Dźwięk często zostaje zdeformowany, wyostrzony, a nawet nałożony, np. upadek podkreślony jest specjalnym brzmieniem wzmacniającym odbiór, a nawet tragizm sytuacji; deformacja poprzez spowolnienie emisji, obniżenie tonu (funkcja komiczna w zestawieniu z obrazem wypełnionym wykrzywioną w grymasie twarzą).

Mniej dynamiczne i głośne są ujęcia składające się na reality game show. Przypominają one sceny z Big Brothera. To głównie rozmowy, pokój zwierzeń oraz inne codzienne czynności, takie jak: jedzenie, mycie, wieczorne rozmowy. Są oni jednak mniej aktywni, bo wyczerpani forsownymi konkurencjami. Trzeba jednak zaznaczyć, że nie jest to program z rodzaju batsu games i, mimo że uczestnicy poddawani są wysiłkowi na granicy ich wytrzymałości, nie wymierza im się kary cielesnej za niewykonanie zadania. Nie znaczy to jednak, że nie odczuwają oni bólu. Jest on jednak efektem ubocznym konkurencji bądź odniesionych kontuzji.

Wyjątkowość (szczególnie pod względem społeczno-kulturowym) produkcji japońskich dobrze ilustruje I Survived a Japanese Game Show, jako że ukazuje zderzenie dwóch kultur - japońskiej i amerykańskiej.

Uczestnicy to dwunastu obywateli Ameryki pochodzących z różnych jej stanów. Podzieleni na dwie grupy - Zielone Tygrysy i Czerwone Roboty (seria I) i Żółte Pingwiny i Zielone Małpy (seria II) - rzeczywiście ze sobą rywalizują (obrażają się, wyzywają, oskarżają, winią). Różnią się między sobą zawodem, statusem społecznym i majątkowym, rasą, wyglądem (np. atrakcyjnością, wagą) oraz sprawnością ${ }^{19}$. Podobni są: wiekiem (wszyscy młodzi), ambicjami (każdy chce zdobyć wygraną), pewnością siebie (wrodzoną albo narzuconą przez formułę programu - każdy się wywyższa, jest pewny wygranej). Ta pewność siebie to często zwykła zuchwałość, można jednak z całą pewnością stwierdzić, że Amerykanie mają jak najlepsze zdanie o sobie, są wręcz przekonani o swojej wyjątkowości. Nikt z nich nigdy nie wyjeżdżał poza granice Stanów Zjednoczonych. Nie wiedzą nic o Japonii (dziwią się nawet wyglądowi zawodników sumo), ale są nią zachwyceni. Z drugiej strony jawią się jako głośni i irytujący ignoranci, którzy nie mają pojęcia albo nie obchodzi ich, jak żyją i funkcjonują inne narody. Biorą udział w tym programie, bo potrzebują pieniędzy, często to podkreślają. Bardzo się ekscytują, cieszą się z wygranej, z nagród, ale też równie mocno przeżywają porażki, płaczą, wydają się załamani. Mieszkają w tradycyjnym japońskim domu na przedmieściach Kasai. Opiekuje się nimi Mama-san - gospodyni i przewodniczka po japońskich zwyczajach, kulturze, a przede wszystkim tradycyjnych potrawach. Dom jest luksusowy, wypełniony japońskimi przedmiotami użytkowymi i dekoracyjnymi.

Prowadzący i jego pomocnicy, sędzia, publiczność i realizatorzy to Japończycy, w większości niemówiący po angielsku. Prowadzący część playoff reality to urodzony w Tokyo, a wychowany w Stanach Zjednoczonych Tony Sano. Gospodarz modern game show Rome Kanda jest niezwykle charyzmatycznym aktorem i komediantem grającym w programie pierwsze skrzypce. Jego pomocnicy to grupa mężczyzn w czarnych garniturach „sayonara mob” (ucharakteryzowanych na członków jakuzy), którzy każdorazowo na rękach wynoszą wyeliminowaną z programu osobę przy dźwiękach muzyki i śpiewie publiczności: Sajonara, Sajonara. W związku z tym, że zadania te nie są do końca sprecyzowane, jasne, w kluczowych i spornych

19 Dla przykładu, w serii I wystąpili m.in. Megan (29) - sprzedawczyni akcesoriów dentystycznych z Chicago, Bobaloo (35) - sprzątacz kaliforniejskich mieszkań, Brent (29) - instruktor Salsy, Yari (23) - księgowa z Bronxu, Justin (22) - kelner z Pitsburga, Kimberly (26) nauczycielka z Philadelphi, Drew (29) - adwokat z Saint Louis. 
momentach rozstrzyga bezdyskusyjnie Sędzia Bob. Japońska publiczność jest bardzo głośna. Zawodnicy w trakcie zadań nie mogą się porozumiewać. Publiczność się śmieje i drwi, pokazuje palcami, albo po prostu dobrze bawi, oglądając rywalizujących ze sobą Amerykanów. Tak samo reagują, kiedy w innych reality game shows walczą Japończycy. Kpią, śmieją się z uczestników nazywając ich: ofiarami (nie zawodnikami), biednymi, poor bunnies. Prowadzący mówi po japońsku, by nie zostać przez nich zrozumianym (np. „Mam gdzieś to, kto wygra, ważne by się skąpał”; „Proszę o aplauz tych, którzy uważają, że Amerykanie wyglądają głupio w tych strojach”). Amerykanie, nie rozumiejąc i nie wiedząc, że oni się z nich śmieją, cieszą się, biją brawo, chociaż sami również śmieją się z tych, którzy biorą udział w eliminacjach. Trudno ocenić, czy wynika to z powszechnej niechęci Japończyków do cudzoziemców. Przybysze z innych krajów, których ciągle w tym kraju niewielu, nazywani się gaijinami, co ma raczej pejoratywny wydźwięk. Wynika on z obawy przed obcymi, ich nieprzystosowaniem do panujących sztywnych zasad, ale też z przekonania, że są po prostu gorsi ${ }^{20}$.

\section{3.}

I survived a Japanese Game Show to ciekawy przykład analizy specyfiki japanese-style extreme shows, ale też wyjątkowości japońskiej, a przy okazji i amerykańskiej kultury. Pozwoli ona na wyjaśnienie choć niektórych aspektów tego unikalnego na skalę światową telewizyjnego zjawiska ${ }^{21}$.

Amerykanie uczestniczący w programie są bardzo ekspresyjni, głośni na co dzień, w studiu, w domu, podobnie jak większość ich rodaków. Japończycy to naród mocno powściągliwy na co dzień, ale głośny w miejscach do tego przeznaczonych, takich jak: dyskoteki czy popularne pachiko bary (gdzie można ogłuchnąć od muzyki i dźwięków maszyn do gier, a gdzie, paradoksalnie, Japończycy potrafią się najlepiej skupić), a także Soho Studio, w którym odbywał się modern game show. Japończycy są powściągliwi poza studiem, a w nim ogrania ich „szał”. „Japoński humor ma skłonność do przybierania skrajnych form, które mogą kojarzyć się z reakcjami histeryków”22. To efekt tłumionego przez wieki (głównie w czasie epoki Samurajów) śmiechu oraz czasu, w którym Japończycy przybrali maski ludzi bez emocji, pozwalając sobie na prawdziwe przeżywanie jedynie w głębi siebie ${ }^{23}$. Japońska powściągliwość wyraża się ponadto $\mathrm{w}$ formule programu. Jako że jest to reality game show, zawodnicy z reguły pokazywani są w oderwaniu od swojego otoczenia, nic o nich nie wiemy, kreują się na nowo. Jednak w momencie opuszczenia studia ukazuje się ich dom, rodzinę, środowisko. Tutaj tego nie ma. Poza wskazaniem wieku, zawodu i miejsca zamieszkania do końca programu nie uda się nam dowiedzieć o uczestnikach niczego więcej. Mieści się to $\mathrm{w}$ formule wszystkich japońskich reality shows. Japończycy, w przeciwieństwie do osób innych narodowości, nie zwykli wyrażać swoich uczuć przed kamerą, tym bardziej że nie byłoby to interesujące dla widzów, wywołałoby znużenie i nudę. $Z$ tego też powodu, a także

20 R. Tomański, op. cit., s. 223.

${ }_{21}$ Pomocne w tym będą m.in. książki: E. T. Hall, Ukryty wymiar, Warszawa 2009; G. Hofstede, Kultury i organizacje: zaprogramowanie umysłu, Warszawa 2000; H. C. Triandis, Collectivism vs. Indyvidualism, [w:] Cross-cultural studies of personality, attitudes and cognition, red. G. Verna, C. Bagley, London 1988.

22 R. Tomański, op. cit., s. 189.

${ }^{23}$ Ibidem, s. 189. 
z kolektywizmu mocno zakorzenionego w kulturze Japonii, nie są tam popularne programy spod znaku Big Brothera ${ }^{24}$. Wyjątkiem są celebryci, ci zawsze interesują publicznośćc ${ }^{25}$.

Uczestnicy I Survived a Japanese Game Show utrzymują niewielki dystans przestrzenny między sobą, mniej więcej na pół długości ręki, a nawet mniej. Często się dotykają (przybijają piątki, przytulają, skaczą na siebie, poklepują). Kiedy zbliżają się do Japończyków wielokrotnie widać u tych ostatnich skrępowanie, zdrętwienie i zażenowanie. Wielokrotnie też, bezpośrednio do kamery, wypowiadają się z wyraźną mimiką i ożywioną gestykulacją. Widać to najlepiej w czołówce programu, gdzie przedstawiani są poszczególni bohaterowie w bogatej palecie ekspresyjnych min. Potrzebują dla siebie przestrzeni, której często nie mają i prywatności (niekoniecznie intymności, nie mają choćby skrupułów przed rozebraniem się przed kamerą). W Japonii inaczej. To kraj mocno zaludniony, szczególnie w obszarach miejskich, gdzie ludzie mieszkają na małych, często nieoddzielonych przestrzeniach. To też ciągle kraj bardziej kolektywny.

Społeczeństwu i kulturze japońskiej obcy jest indywidualizm Amerykanów. Ci są podzieleni na grupy, jednak nie mają poczucia wspólnoty. To zbiór indywidualistów, egocentryków, stawiających siebie w centrum (wielokrotnie podkreślają, że nie przyszli tu szukać przyjaciól, tylko wygrać pieniądze). To potwierdza zauważaną szczególne u młodych Amerykanów postawę, cechującą się nienastawianiem na długotrwałe relacje, zawieraniem krótkotrwałych umów, wchodzeniem w niezbyt głębokie i krótkotrwałe związki. Raczej też nie kierują się emocjami, choć je okazują (nie boją się okazać gniewu, strachu, a nawet płaczu). Zupełnie inaczej w japońskich reality game show. Nie ma w zasadzie indywidualizacji (nie podaje się żadnych informacji o zawodnikach poza imieniem, czasem nazwiskiem), pluralizacji dążeń i działań. Zgodnie z zasadą kolektywizmu każdy z nich pracuje na konto swojej drużyny. Zespołowe teleturnieje przeważają też w tamtejszej telewizji.

Osoby biorące udział w japońskim modern game show mają o sobie dobrą opinię i silną potrzebę jej wyrażania. Oczywista arogancja jest właściwością ich kultury. Są entuzjastyczni. Dla większości ważna jest spójność pomiędzy postawą i zachowaniem, jej brak określają jako hipokryzję. Nie widzą specjalnej różnicy pomiędzy zachowaniem publicznym i prywatnym. Nie mniej jednak, jeśli chodzi o program i pieniądze, które wydają się dla nich w tym momencie najważniejsze, zasada ta przestaje być najważniejsza, a dokładniej, prawie wszyscy zawodnicy wymagają lojalności od innych, ale nie od siebie. Na co dzień komunikują się i wyrażają jasno, jednak formuła programu (konieczność eliminacji) sprawia, że zdani są na porozumiewanie niebezpośrednio, a za plecami innych, najczęściej zainteresowanych.

Biorący udział w japońskim reality Amerykanie charakteryzują się myśleniem logicznym, przyczynowo-skutkowym (widać tu szczególnie elementy kultury protransakcyjnej), są nastawieni na wykonywanie konkretnych zadań. Nie wybiegają w przyszłość, skupiają się na danej chwili. Tego też wymaga od nich formuła programu. Nie polegają też na innych, tak jak ma to miejsce w japońskich teleturniejach, w których odbijają się elementy kultury propartnerskiej, gdzie poszczególni zawodnicy w danej grupie wzajemnie się wspierają, pomagają sobie, dopingują, nie rywalizują. Zaciętej rywalizacji próżno szukać również w walce między dwiema drużynami, najważniejsza dla Japończyków jest dobra zabawa.

${ }^{24}$ M. Keane, A. Y. H. Fung, A. Morans, New Television, Globalisation, and the East Asian Cultural Imagination, Hong Kong 2007, s. 153.

25 U. Rohn, op. cit., s. 303. 
Amerykanie mają luźne podejście do obowiązków i panujących zasad w przeciwieństwie do Japończyków. Potrafią odmówić wykonania zadania, są niepunktualni. To wyraźna różnica między Japonią a Ameryką, a więc kulturą ceremonialną i nieceremonialną. Ważna jest dla nich dobra zabawa, ale w tym programie najważniejsze są pieniądze. Podkreślają, że są im bardzo potrzebne i są dla nich w stanie zrobić wszystko (niektórzy stawiają je wyżej niż własne zasady, np. dane słowo). Sami i szybko podejmują decyzje. Nie jest dla nich problemem wyznaczyć kogoś do eliminacyjnej rundy. Wśród Amerykanów panuje przekonanie również o niższości i słabości płci pięknej. To ciekawe, gdyż równie często jak siła, do wykonania poprawnie zadania potrzebna jest sprawność, zręczność, i to wtedy wygrywają kobiety, przyczyniając się do zwycięstwa drużyny. To przekonanie często gubi Amerykanów, błędnie zakładają niższość i słabość kobiet biorących udział w konkurencji (nawet polegającej na jak najszybszym przebraniu się) i przegrywają. W japońskich modern game show przeważają mężczyźni. Wynika to zapewne z charakteru programów - trudnych do wykonania bądź opartych na systemie kar zadań. Japończycy zachowują większy dystans władzy niż Amerykanie w życiu codziennym, nawet w reality show. Konkurencje przez nich przygotowane nie są jasno sprecyzowane i przejrzyste. To wynika najprawdopodobniej z wysokiego kontekstu ich kultury, w której nie wszystko jest dopowiedziane, a wynika raczej z kontekstu (stąd potrzeba obecności Sędziego Boba). Amerykanie, u których dystans władzy jest mniejszy, respektują jednak dominującą pozycję gospodarzy programu.

4.

Pierwsza seria I Survived a Japanese Game Show - kolorowa, hałaśliwa, przepełniona energią, ale i okrucieństwem - spodobała się Amerykanom. Pojawiły się o nim opinie, że te zawody są „tak głupie, że aż zabawne w swojej głupocie”, oraz że nie wymagają myślenia, co uznano za atut. Zdania te wpisywały się w zamierzenia twórców, co odebrano jako pełny sukces $^{26}$. Druga seria już nie cieszyła się tak dużą oglądalnością i zdjęto ją z anteny w 2010 roku. Powodem słabego zainteresowania było prawdopodobnie wyczerpanie się formuły programu. Amerykanie, mimo iż niezbyt wymagający wobec mass mediów, inaczej niż Japończycy, lubią zmiany i element zaskoczenia, i tego im najprawdopodobniej zabrakło $\mathrm{w}$ drugiej serii. Japończycy natomiast latami mogą oglądać niezmiennie ten sam teleturniej z jednym do wykonania (bądź raczej niewykonania) zadaniem. Niemniej jednak I Survived a Japanese Game Show ukazal Ameryce i Europie istotę japanese-style extreme shows opartych na trudnych, niemal niemożliwych do realizacji poleceń, gdzie największą nagrodą jest uniknięcie kary bądź tylko aplauz publiczności.

W zbliżeniu się do poznania fenomenu ich popularności może pomóc próba zrozumienia japońskiej mentalności; tego, że na każdym jej polu można wskazać jakąś dwoistość ${ }^{27}$. To „rozdwojenie osobowości” Japończyków przejawia się najpełniej w rozdźwięku między ich publicznym (w pracy, szkole) a prywatnym (w wolnym czasie) wizerunkiem. Widać ją również na przykładzie reality game shows, w których poważni, cisi i powściągliwi Japończycy pokazują swoje drugie oblicze, pozwalając sobie na ekspresję tłumionych za dnia

\footnotetext{
26 J. Gillan, Television and New Media. Must-Click TV, Nowy Jork 2011, s. 173.

27 R. Tomański, op. cit., s. 257.
} 
uczuć. Z drugiej strony ekranu widzowie śledzą głośne i przejaskrawione estetycznie show kontrastujące mocno ze stylistyk wnętrz ich cichych, stonowanych, skromnie i harmonijnie urządzonych mieszkań. Dwoistość ich natury widać również na przykładzie innych wytworów medialnych. „Emanująca przemocą kultura masowa Japonii, agresja obecna w kulturze komiksów, filmów czy programów telewizyjnych umożliwia Japończykom życie w harmonii i spokoju na co dzień” ${ }^{28}$. Oglądanie przez Japończyków na ekranie i scenie od wielu dekad aku no bi, czyli „piękna zła” czy „negatywnego piękna” pod postacią obrazów krwi, cierpienia i śmierci udowadniających często najwyższe wartości takie jak: wierność, honor i męstwo, a nawet nadających życiu sens (co zgodne z historią i kulturą narodu) ${ }^{29}$ wyksztalciły inny rodzaj wrażliwości, „odmienny od bardziej wyrafinowanego i mniej dosłownego zachodniego" ${ }^{\prime 3}$. W rezultacie przemoc i okrucieństwo zagościły na stałe w japońskich mediach, a tym samym w programach reality show emitowanych w czasie największej oglądalności, a zatem łatwo dostępnych dla dzieci, i nie wywołują w nich negatywnego wrażenia. Nowoczesne teleturnieje z dziwacznymi konkurencjami już tylko śmieszą i bawią. Inaczej jest z ich odbiorcą spoza Kraju Wschodzącego Słońca. Ten, im większą posiądzie na ich temat wiedzę, tym lepiej mu będzie choć w części pojąć współczesne, tylko w Japonii występujące zjawiska, jednak zrozumienie całej złożoności kultury tego kraju pozostanie najprawdopodobniej niemożliwe.

28 J. Hendry, Tradition, Escapism and Occupation: Examining Japanese Mass Media, cyt. za: R. Tomański, op. cit., s. 199.

29 Zob. P. Kletowski, Kino Dalekiego Wschodu, Warszawa 2009, s. 19-73.

30 Ibidem, s. 198. 